Man and Nature

L'homme et la nature

\title{
Canonic Art: Pregnant Dilemmas in the Theory and Practice of Anton Raphael Mengs
}

\section{Calvin Seerveld}

Volume 3, 1984

URI : https://id.erudit.org/iderudit/1011829ar

DOI : https://doi.org/10.7202/1011829ar

Aller au sommaire du numéro

Éditeur(s)

Canadian Society for Eighteenth-Century Studies / Société canadienne d'étude du dix-huitième siècle

ISSN

0824-3298 (imprimé)

1927-8810 (numérique)

Découvrir la revue

Citer cet article

Seerveld, C. (1984). Canonic Art: Pregnant Dilemmas in the Theory and Practice of Anton Raphael Mengs. Man and Nature / L'homme et la nature, 3, 113-130. https://doi.org/10.7202/1011829ar

Copyright (C Canadian Society for Eighteenth-Century Studies / Sociéte canadienne d'étude du dix-huitième siècle, 1984
Ce document est protégé par la loi sur le droit d'auteur. L'utilisation des services d'Érudit (y compris la reproduction) est assujettie à sa politique d'utilisation que vous pouvez consulter en ligne.

https://apropos.erudit.org/fr/usagers/politique-dutilisation/ 


\section{Canonic Art: Pregnant Dilemmas in the Theory and Practice of Anton Raphael Mengs}

The problem of canonic art recurs in history. Whenever artists and aesthetes assume leadership because they are dissatisfied with the state of artistry, are intent upon significantly changing a reigning style, or feel called upon to defend the status quo, such leaders in the artworld exercise certain preferences, lending their authority to their choices. The choices made by leading artists, theorists, critics, and even art patrons, have a way of assuring that the ensuing art is normative, a canon for subsequent art. The dilemmas concealed in this establishment of canonic art surface with special clarity and historical importance in the work of Anton Raphael Mengs (1728-79).

Mengs was a published art theorist to whom the renowned Winckelmann dedicated Geschichte der Kunst des Altertums in 1764. Mengs was also a celebrated artist. In 1751 he was named principal painter at the Dresden court of Augustus III, King of Poland. In 1759 he was commissioned in Rome by Cardinal Albani to do the crowning fresco of the galleria nobile of the whole villa complex which served as salon for papal entourages and for illustrious visitors from foreign lands. In 1763 Mengs was instated as Director of San Fernando to establish a Spanish national Academy of Art. He became the principal painter at the Madrid court of Charles III in 1766. Pupils tutored by Mengs and younger kindred spirits became directors of art academies and their curricula in Turin, Stuttgart, Dresden, Karlsruhe, Copenhagen and Vienna. ${ }^{1}$ Mengs was also a profes- 
sional art historian who both assisted and corrected Winckelmann, perhaps even spoofed him, in the analysis of Graeco-Roman art discoveries. ${ }^{2}$ Mengs' method of art criticism supplied Goethe and Heinrich Meyer with what they needed to give their classicist Weimar Kunstfreunde direction. ${ }^{3}$

That is, Mengs practised an uncommon range of artistic tasks, and had the freedom of position - especially as a gifted outsider asked to come into a cultural situation - to formulate his ideas about artistic excellence. Mengs was able to define a coherent praxis and policy for art. His tenets are worth analysis, especially if we recognize that the problem of giving leadership in painting is a matter of vital importance for the artworld of any day. Are there ways to posit artistic norms, canons for art, that will be neither dogmatic nor laissez-faire? Can the conception of canonic art be fruitful rather than abortive?

\section{The six theses of Mengs' art theory}

Gedanken über die Schönheit und über den Geschmack in der Malerei took shape during conversations with Winckelmann in Rome and was finally published in 1762 in Zürich by the father of Henry Füssli. The core doctrines of Mengs' theory are clear: (1) There is an invisible, absolute, divine Perfection in which each form of Nature participates, according to its specific, graduated destiny $(1: 9,13,15) .^{4}$ (2) Anything which visibly conforms to our idea of its telos is considered beautiful, because Beauty is visible Perfection $(1: 7-8,10-12,17,21)$. (3) Since some things are more beautiful than other things, good taste is the rational selection of the most beautiful forms of Nature (1:26-30). (4) The art of painting, like poetry and music, can surpass Nature in Beauty, 'meliorate the things in Nature,' because the artist, like the bee extracting sweetness from many flowers to make its honey, can freely choose to imitate the most beautiful parts found here and there in Nature for composing the artwork (1:18-19, 30, 51).

In the important treatise of 1776 addressed to Don Antonio Ponz, secretary of the Royal Academy, San Fernando, Mengs takes a stand on matters then current which gives his theory of canonic art its cachet: (5) This painterly imitation of what is essential in the natural objects perceived - using design, chiaroscuro and colour - should be ideal, and will be 'the more valuable as the idea conveyed will be perfect, distinct, and clear' (P, 10-13). ${ }^{5}$ (6) Grecian artists have excelled in perfecting the over-all rendition of Beauty; but even the Greeks would be astonished at the admirable precision of expression in Raphael's design (P. 52, 106), and although Correggio is not so great as Raphael in paint- 
ing mental states, Correggio painted bodies in chiaroscuro so enchantingly he 'completed' the art of painting, and 'was the meridian of the art: from that point it always went declining' (3:53); and Titian is the master of true colouring. These three artists in their respective strengths are the touchstones for painterly art and the best taste $(1: 20,37-38,40,78$; , 44-45). By way of digression, it should be mentioned that Mengs elaborates in theory what he preaches for artistic praxis; it is unfair to brand his amalgam of ideas eclectic or muddled. ${ }^{6}$

Certainly, Mengs' description of the five principal parts of painting in which 'invention' and the 'composition' subservient to it form the principles constituted by design, chiaroscuro, and colouring ( $P, 36-43$, 98-103; 3:96-97) repeats what had become a commonplace among European artists and thinkers since the writings of Vasari and Dolce, Lomazzo and Zuccaro. ${ }^{7}$ Mengs' metaphysic of Beauty, trailing thin Meso-Platonic clouds of deity in Nature which our rational soul inspects to find what comports there with our human idea of the more and most beautiful (1:22-23, 30), articulates precisely the major thesis of Batteux's Les beaux arts réduits à un même principe (1746), namely, 'l'imitation de la belle nature.'

The fact that Batteux's thought was in vogue among Germans after Schlegel's 1751 translation, ${ }^{8}$ the fact that the writing of Mengs constantly echoes Bellori and the Italian art theorists of cinquecento, ${ }^{9}$ and the fact that Lomazzo was Mengs' favourite reading ${ }^{10}$ are all evidence that Mengs was steeped in tradition. His theory of beauty, taste, and art, far from being a pastiche of odd thoughts, is intellectually coherent. His theory even conforms to the age-old epigram of Zeuxis, updated: cross expression from Raphael's design, harmony from Correggio's chiaroscuro, and true representation from Titian's colour, and moderate your inventive composition with the Greek spirit of reserved perfection, and you have the summum bonum of Beauty, taste, and painterly art (1:37-41 \& 1:part III passim).

Whether Mengs appropriated the Zeuxis fable from Bellori or (more probably) from Lomazzo, Alberti, and Pliny, or first heard of it in conversation with Winckelmann ${ }^{11}$ neither matters nor detracts from his genius in having turned it into a theory of art tied to a practical norm of visible Beauty and taste with a canon for painting that could be known, taught, and was believed to be important for the state of what Pico della Mirandola earlier called De hominis dignitate (1:33). And Mengs put these 'Thoughts' down in writing which was accessible to non-specialists, in short chapters that should have warmed any popularizing encyclopedist's heart. His Gedanken antedated Schiller's short series of letters Über die Ästhetische Erziehung des Menschen (1794-95) by a genera- 
tion. Nothing systematic like Mengs' Gedanken had appeared in German before 1762. No wonder it was acclaimed and went through five editions before his death. ${ }^{12}$

A close scrutiny of the texts corrects the unfavourable Romantic reading given them and might end superficial characterization of his theses about canonic art.

Despite the Meso-Platonic flourishes of his doctrine, Mengs' basic approach is not speculative, but is Aristotelian. ${ }^{13}$ His theory of imitation takes its cue from Aristotle's conception of mimesis, according to which the artist seeks to re-present 'the motive of its model.' Mengs explicitly contrasts such 'imitation' with Plato's concept of the journeymanlike copy $(1: 35,44 ; 2: 105 ; P, 10-12,112-116)$. The artist-theorist Mengs also very matter-of-factly gives precedence to training of the eye and hand over learning rules for art. Extrapolating from his own history, Mengs unequivocally posits that practice and execution should precede theory and scientific rules in the education of an artist (1:3). Such are not the dicta of a scholastic, arm-chair theorist.

While Mengs shared with Winckelmann a connoisseur's veneration for the art of antiquity, Füssli was wrong to lump them both together as antiquomanes. Mengs was a conservationist in theory, but he valued the Greeks not because they were the faultless paradigms Winckelmann somewhat indiscriminately believed them to be, but because the Grecian painters, by moderating their artistic attempts to cover equally well all the necessary parts of imitating 'the whole of Nature,' had fashioned the best examples of complete Beauty (1:38-39, 75-77). For Mengs the paragons of painting are Raphael, Correggio, and Titian. That fact helps distinguish what Mengs is doing in 1762 from the antiquarian concerns of Winckelmann but also from the habit of latching onto 'Greek connections' prevalent with a Mannerist thinker like Junius (1512-75) or with Bellori (1615-96).

The distinctions are nice, but such fine distinctions are important if art historians are to assess accurately what is historically particular in Mengs' 'neoclassical' thinking. Cinquecento theorists used the rhetoricians of antiquity to bolster painting's claim to be as honourable as poetry, and did it often rather pedantically. Seicento thinkers on painting were not concerned with an apology for painting so much as justifying la grande manière with an aura of ancient themes and classical detail (cf Poussin) and reinterpreting Graeco-Roman theories with an academic accent. Mengs, however, simply includes, and thereby relativizes, the Graeco-Roman statuary, the tales of Greek painting (and the findings at Herculaneum after 1738), as Exhibits A, so to speak, in his pantheon of canaonic art which is filled with other exhibits. 
Although he would whistle the allegro of a Corelli sonata while painting an 'Annunciation' and switch to a melody of Dorian mode for Deposition from the cross, ${ }^{\prime 14}$ and although he continually drops phrases, for example, in describing 'invention' as 'the essence and poetry of a picture' (P,99-100), Mengs is not at all concerned with arguing about ut pictura poesis or the 'correspondences' between painting and music. That vocabulary is simply the idiom in which Mengs focuses all his attention upon bringing an encyclopedic theory of canonic art ('all those parts' of painting, 'all the rules of the art' [my italics], 1:3) into play practically, for beginning, intermediate, and professional painters (1:4). Mengs' theory is 'neoclassical' only in the sense that it reveals a belief in ancient fundamentals (2:145-46), the 'tried-and-true' ideas and methods accumulated throughout the ages which he trusts will reintroduce an enlightened understanding and performance to the art of painting.

There are two dilemmas posed by Mengs's theory of canonic art that need particular attention, one stemming from the systematic structure of his aesthetic theory (theses 1-4), and a second from his neoclassical temper (theses 5-6).

Firstly, if the best Beauty the art of painting achieves is one of supernatural simplicity ${ }^{15}$ (both by concentrating natural beauties and by neglecting encumbering minutiae $[2: 113,116 ; \mathrm{P}, 11])$, will the best painterly art tend to leave actual 'Nature' behind and use objects only to reflect Beauty? ${ }^{16}$ And if the most noble part of painting is to rouse (but not ruffle!) our 'generous passions' and to instruct the human mind $(2: 95, P, 9-11,90)$, must painters reinvest the normative geometric uniformities and perfect primary colours, - upon whose infinite variety painterly beauty depends (1:10-13), - with 'poetic' ideas, or not? ${ }^{17}$

Secondly, if the art of painting attains the most sublime degree of beauty and perfection the ancient Greeks gave it (1:20-21), is the only possible historical change one of decline (2:117)? Or, if painting is always more or less perfect (cf 'gradations of Beauty,' 1:15), what makes the 'rise, progress, and decay' of canonic art possible as a pattern? And if any human act, which is imperfect, can be 'carried to a higher degree' of perfection $(1: 24,80)$, why is it doubtful that another Athens might appear in Italy (1:21)? - can Athens not repeat itself?

That is, surrounded by the legitimation of decorative, easy-going art ('adapted to the discernment of those who employ us,' writes Mengs in a wry note), and aware of the ongoing loss of a literary tradition in the art of painting, Mengs unfolds a theory which combines a secularized theology of Beauty with a humanist philosophy of history. He proposes as canonic art the kind of painting which imitates 'Nature' - halfunderstood to be 'the best of the Western tradition of art.' Although 
Mengs slips into this position more by way of practical, pedagogical concerns than of carefully argued, philosophical reasons $(1: 40,78)$, the problematic import for theory of art is still serious: canonic art becomes essentially a kind of palimpsest.

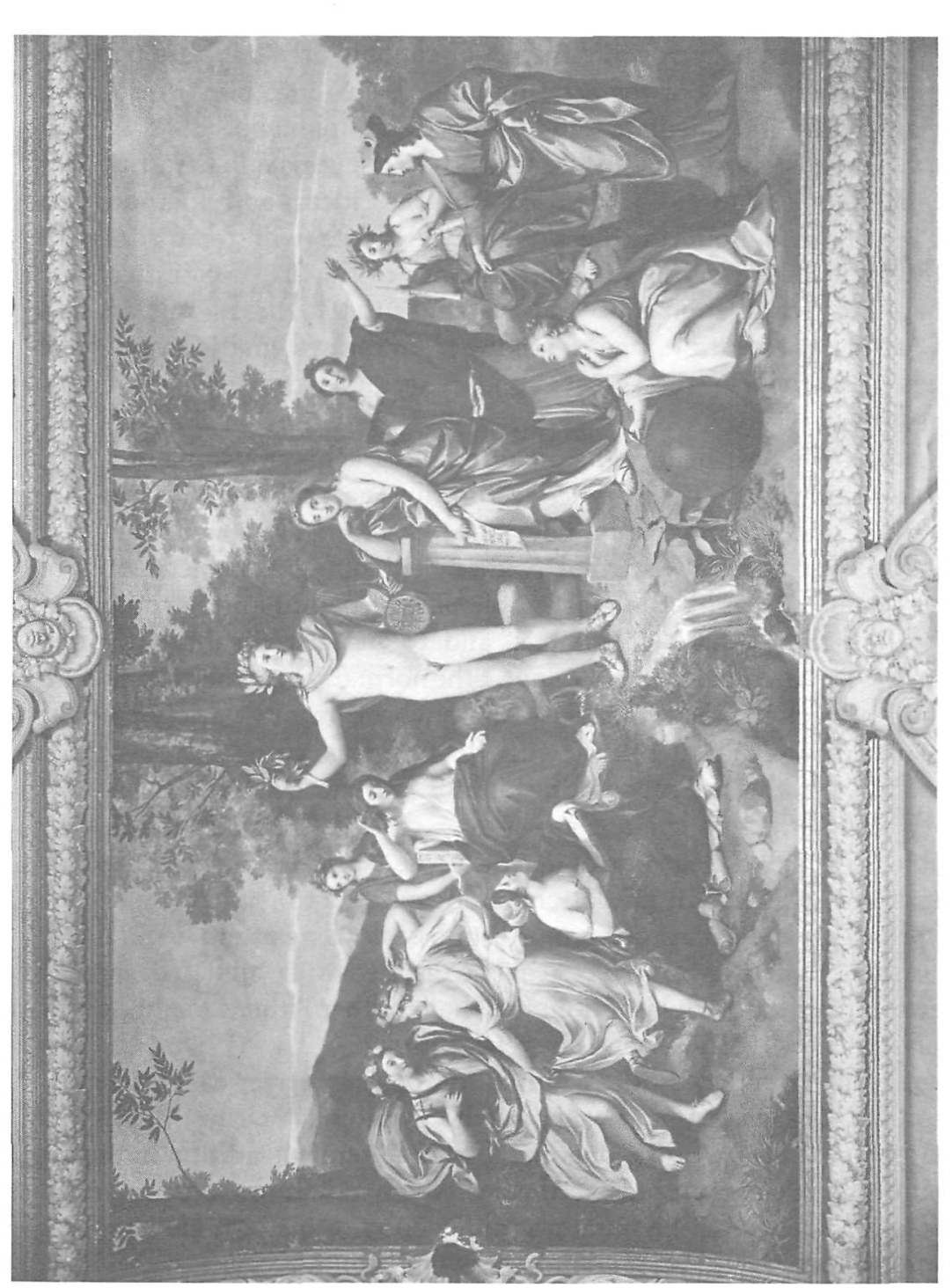


Evidence for this reading of Mengs' theory and its dilemmas is at hand in the Parnassus fresco he painted in the villa Albani (1760-61). The exhaustive detective work by Steffi Röttgen on Parnassus with its flanking tondi and an earlier drawing that shows compositional change in the final painting, which she has put in context by examining all relevant treatments of the topos ${ }^{18}$ has iconographically unpacked every graphic hint in the piece. Most important is this: the god Apollo surrounded by the nine Muses prepares for the coronation of Albani as the reigning seigneur of the new Mount Olympus found at 'eternal' Rome, and gestures in presentation toward the most favoured position of Calliope, muse of painting, who leans pensively on a Doric column, signifying ancient art, and holds a scroll inscribed with the name of Mengs. Mnemosyne, mother of the Muses, seated on Apollo's right, hand to ear as prescribed by Ripa, and pointing to the spring of fresh water at Apollo's feet, emblematizes mnemonics, the art of remembering, which, in a tradition running from Cicero to Lomazzo and onward, was an art assigned especially to painting. Painting makes abstract ideas concretely vivid and memorable; painting functions par excellence commemoratively, making the past present. ${ }^{19}$ So, like a mirror mirroring a mirror, Mengs paints the meaning of painting, that is, the best art for making present idea-filled Greek art in all its excellence.

The whole conception of Cardinal Albani, counseled by Winckelmann, was to effect a genuine restoration of Greek art in a natural setting that would give the lie to everything artificial. Every piece of authentic ancient art the Cardinal owned would be housed so as not to seem antique. Albani did not want his villa to be a museum, a showcase of replicas, ${ }^{20}$ but to recapture the glory of a real ancient Roman villa alive with Greek art. Every artwork must not seem but be Greek. Because there was no genuinely Greek painting among the Cardinal's fabulous cache of sculptures, marble columns, bronzes, mosaics, dishware, reliefs and valuables, Mengs was commissioned in 1759 to produce a Greek painting that would both celebrate this new centre of Greek art and be its climax.

Mengs fulfilled the commission according to the specifications of Winckelmann, who had formed strong opinions from his literary sources about what Greek painting must have been like. Two criteria are evident: one, the painting be a repository of images replete with poetically fashioned, universal ideas (algemeine Begriffe) ranging from mythology to the secret wisdom of many peoples, the more exquisite the allegorical dress the better; ${ }^{21}$ two, Greek sculpture should be the paradigm for the painterly composition. ${ }^{22}$

This last criterion, which complements Winckelmann's remythologiz- 
ing, literary concern, is of historical importance because it explains the feature which startled contemporaries of Parnassus into admiration and made them believe a new artistic era was dawning. There was precedent enough for the vertical perspective and non-illusionary space in quadri riportati done by Annibale Carracci, even Pietro da Cortona, Guido Reni and others who had decorated ceilings in gallerie of Roman palazzi. ${ }^{23}$ Mengs certainly needed to follow that local taste and could not allow the figures above the spectators to soar off into a baroque heaven when the whole point of the commission was that the Muses have taken residence here on earth! But the sculptural feel in the painterly line provoked eyes to see something new. The contour of each figure poised like a solitary silhouette, separated from the others, and tastefully arranged in an oval tableau struck the viewer surfeited on composizioni macchinose as singularly different, an incredibly uncluttered, pure, restful presentation of truly living figures, statuary paragons of immortal, gracious beauty.

Parnassus is not the work of a neophyte who mimicked the Raphael piece in the Vatican, ended up with an artificial collection of mannered individuals who lack organic unity, and was praised excessively by his famous friend Winckelmann. This is the Romantic misreading which has become largely the official one. ${ }^{24}$ Mengs knew precisely what he was doing and did it masterfully: painting a Greek painting! This entailed following Winckelmann's sculptural prescription (which certainly took precedence over 'copying' any Roman remains found at Herculaneum). ${ }^{25}$ Mengs assumed that the Greeks bestowed great assiduity on single objects and that their most celebrated paintings and statues 'did not form one grand unity, but only an assemblage of figures, which had their particular excellence' $(P, 45)$. Further, Mengs believed Raphael, whose genius penetrated the truly beautiful style of the ancients, was held back by the ignorance of his own times about Greek customs and ideals; Raphael's own genius 'could not entirely abandon humanity, with the happy success of the ancient Greek painters' who ranged freely 'between the heavens and the earth' $(1: 49,62 ; 2: 101)$.

Mengs' Parnassus was artistically premeditated; it is a principled manifesto for the remaking of Greek painting, which yet is, palimpsestically, thoroughly pro-Raphaelite. Unlike Raphael, Mengs had seen the Apollo Belvedere; so Mengs' Apollo stands naked. Mengs' improved knowledge of Greek ideals, he believed, permitted him to perfect Raphael, that is, return Raphael's genial art to a more unearthly, Greek divine Beauty.

A brief remark en passant can tie the analysis so far into a larger problem. One could do worse than remember Mengs' fresco Parnassus as 
touchstone for a graphic definition of what 'neoclassical' can mean as an art historical term for capturing precisely the cultural spirit of a time which formed by radiation, as it were, a kindred number of artists and writers who constitute a fairly definite and roughly datable period or 'movement' in Western cultural history. Whether certain traits sculptural fixity, powerful linear clarity, serious simplicity - can serve as neoclassical differentia in other arts than painting, and in other painterly artists, for identifying this homogeneous drive to redo Greek (or Roman) art and be 'neo-classical,' will depend upon comparative examination. But there is a method of art historiography that allows for a kind of flexible precision in determining such categories. It can be illustrated in outlining a way to understand Mengs' own painterly development (even though painting by painting analysis cannot be done in this brief article).

Most commentators agree that the Parnassus is quite unlike the rest of Mengs' $e u v r e .{ }^{26}$ Another major problem for interpretation is to sort out the effects of Mengs' double-minded appreciation of Raphael and Correggio, and of his changes in locale, e.g., his moving from Dresden (dominated by Ismael Mengs) to Rome (friend of Winckelmann, rival of Batoni) to Madrid (fierce competition with Tiepolo and Giaquinto), back to Rome, then to Madrid, and again back to Rome.

Although everyone's professional development is a labyrinth of influences, and although every historian mints his own coin of terms, one way to order and understand the stylistic changes in Mengs' painterly art is this (cf schematic note): From 1744-58 Mengs was 'a promising young painter in the Raphael-Maratta tradition,' as Ellis Waterhouse puts it, ${ }^{27}$ who was steeped in a Germanic-courtly rococo spirit. ${ }^{28}$ Around 1759-61 with Parnassus ${ }^{29}$ Mengs' love for Raphael's balanced order and measured use of colour became reinforced by a commitment to neoclassical sobriety which breathed simplification and a new idealism into Raphael's artistic features. Then, from 1762-79, in Mengs' art a submerged predilection for Correggio rose to the surface. A preference for scumbled colour and a warmer grace moderated but perpetuated the neoclassical temper. ${ }^{30}$

An advantage to this kind of analysis for tracking trends and shifts if it stands verification - is the recognition that neo-classical art, epitomized perhaps by the spirit of Mengs's Parnassus, does not need to follow Raphael's paradigm. The neoclassical allegiance - to be the classical ideal anew - can follow Correggio too. There are various types of neoclassical painting. ${ }^{31}$

The pregnant dilemma posed by Mengs' Parnassus for painting is this: how can there be an avantgarde palimpsest, a reconstruction meant to be 
schematic note on shifts in Mengs' style

\begin{tabular}{|c|c|c|c|}
\hline $\begin{array}{l}\text { la grande } \\
\text { manière }\end{array}$ & $\begin{array}{l}\text { rococo } \\
\text { c. } 1715-75\end{array}$ & $\begin{array}{l}\text { neoclassical } \\
\text { c. } 1755-1815\end{array}$ & romantic \\
\hline
\end{tabular}

[Raphael]

Mengs I

Parnassus

(1744-58)

(1759-61)

[Correggio]

Mengs II

(1762-79)

new, painterly reform by return? If one discounts the caterwauling of 'pseudo-classicism' indulged in by critics who have an ideological axe to grind, the dilemma still remains: is repristination of art possible without committing the historical error of becoming anachronistic? How can what is historically past be made the norm for the future without becoming utopian, historically unreal? Can reiteration of a perfect canon be made the norm for art without spawning work that will be, at inception, stale? What is the legacy of the spirit of Parnassus?

\section{Mengs' Framework for Writing Art History}

The dilemma in Mengs' theory of canonic art, which confronts an artist with the task to simplify inventive composition if he wishes to reach a higher degree of Beauty, produces a curious tolerance for both artistry and taste, together with a hierarchy of Beauty. The dilemma in Mengs' praxis of canonic art, Parnassus, which purports to redo perfections of the past, prompts the emulation of the Masters of perfect Beauty, especially if divine Beauty is a teachable ideal in the Academy and can be learned through practice.

The results of Mengs' dilemmas are (1) an ontological breadth to the canon of artistic Beauty that supports Enlightenment tolerance, and (2) a Zeuxian openness to pollinate rosebuds wherever ye discriminately may. When one joins the results of these dilemmas to the artist-theorist Mengs' strong conviction that the artistic elements - design, chiaroscuro and colouring - are central to the purpose and meaning of a painting, then the upshot is an innovative, systematic methodology for 'modern' art historiography, arguably the first. 
Every painter in the polite arts, writes Mengs, has imitated Nature; the only difference is that they have done it in different ways (1:75). The styles in which painters execute the 'picturesque appearance' of their ideas 'are infinite, but the principal ones from which the others should flow, may be confined to a small number' $(P, 14-15)$, five good ones, to be exact, and two unworthy 'manners.'

(1) Sublime style transcends in form any possible perfection found in nature; an abstracted, austere simplicity is its clue $(\mathrm{P}, 17-19)$. (2) Beautiful style is distinguished by imaging every perfection possible, neither slighting nor exceeding any essential quality proper to what is imitated, in its totality $(\mathrm{P}, 19-23)$. (3) Graceful style highlights the gentleness of a modulated chiaroscuro, whose excellent agreeableness is not to be belaboured ( $\mathrm{P}, 23-27)$. (4) Expressive style gives precedence to design, which exhibits by its conforming line the exact, corresponding character of what is represented $(P, 27-29,106-7)$. (5) Natural style is particularly attached to what is casual and amusing; its forte is the colouring of aerial perspective so requisite for being true to everyday life ( $P, 29-32)$.

Some painters, writes Mengs, have made a habit of merely affecting the virtues of other styles, thereby corrupting them. This mannered approach could be called the (A) Vitiated style (P, 33-35). ${ }^{32}$ And painters who potboil artworks for the easy return of popularity may be called exponents of the (B) Facile style ( $\mathrm{P}, 35-36)$.

Mengs has constituted, therefore, without much prejudice, a rough taxonomy of basic styles which provides systematic ordering for artcritical perception. Compared to Diderot's salon reports (begun in 1759) where, with an antipathy for rule-book judgments, Diderot gives voice to the sentiments welling up in him while his connoisseur's eye roves over the painting, Mengs' approach seems as detached and object-oriented as a professional. Compared to Vasari's Vite (1550) where, says Mengs' first editor Joseph Nicolas de Azara with a touch of spleen, the anecdotes often 'treat of everything except what is essential in the Arts, ${ }^{\prime 33}$ Mengs focuses attention rigorously on artistic phenomena. Because Mengs' typology of styles is based upon categories which deal in the hegemony of certain artistic features, he can credit each style with equal artistic canonicity, even though each is more equal than the others as far as its own peculiar patterning and contribution to Beauty goes. ${ }^{34}$

A strength of Mengs' categorical framework for analysis of paintings and sculpture is that it has a comparative scope: the framework can't help but relate and group, weight and contrast, for example, Titian, Velasquez and Rembrandt, who manifest a Natural style, next to Annibale Carracci's male figures, Guido Reni's female portraits, the Venus dei Medici and the torso of Apollo, whose lines, says Mengs, have the 
Beautiful style. A person determines the style of art by examining which artistic element gives the distinctive feature to a piece. This kind of taxonomy in grappling with the art of painting in the 1760s-70s is a genial, not to say original, step on Mengs' part, toward formation of a bona fide art historical method that had been lacking. ${ }^{35}$

Further, Mengs carried his systematic sense of pattern and concern for canonic art over into the problem of temporal succession - the 'History of taste' (1:32-39), the 'Rise, progress, and decay of the art of designing' (2:110-153), and had the uncommon temerity to say:

Painting has partaken of the same vicissitudes and revolutions as all other sublunary things. It has had its bright period, and its fall, has risen again to a certain degree, and now declines once more. It has not only experienced these alternatives, but has varied even in its fundamental principles; for what was considered at one time as an essential attribute, has been coldly looked upon in a successive age, as of no consequence; besides, there has been a contrariety and difference of opinions in various times, relating to those points which constitute the very art itself. $(P, 43-44)$

So alongside his principled commitment to canonic art Mengs had a sure sense of the relativity of times: 'every age has its particular character, which by means of a general ferment, enlivens the imaginations of men' (2:137). But the relative and the normative intersect, according to Mengs, or at least cannot gainsay the fact that the Greeks were the acme of art. The Romans ruined art through opulence, and a barbarous taste arose when Christianity was embraced (2:17-19). The arts revived with Giotto and the study of perspective; the quattrocento artistic geniuses in Italy became models of perfection. After 'a pause,' writes Mengs, the Carracci, especially Annibale, reintroduced the justness of the Greek statues' to painting $(\mathrm{P}, 54)$; Poussin too 'came nearest to the classic style of the Greeks' (P, 57). But Pietro da Cortona, three generations ago, and scholastic disciples of the great painters became superficial, extravagant, and led to the recent ruin of painting (2:130-46; P,55-56).

That this ground plan became standard a generation later need not concern us here. ${ }^{36}$ That Mengs shared Winckelmann's belief that climate brooked large in encouraging or limiting artistic performance and that 'political liberty' and the 'customs' of a land served either as a base for a flourishing artistic community or impaired it (2:3-5, 20-21, 138-39, 144, 147) can be documented. But important for understanding the fruitfulness and the latent sterility of Mengs' neoclassical paradigm about the recurrence of canonic art is to ask pointedly with respect to the writing of art history: does the conception that Greek sculpture and painting was 
the pinnacle of artistic excellence, followed by a fall, and that the quattrocento showed perfection, pause, flurry ... and then a fall, mean that this is an inevitable, recurrent pattern?

Mengs's categorical framework of style-types holds steady, it seems, during changes in painting. ${ }^{37}$ Mengs does not convert his rubric of styles into schematic phases of a lockstep sequence as Winckelmann does when the latter traces the changes in ancient art from the Archaic (ältere) style rising to the Lofty (hohe) style, slipping to the Lovely (schöne) style and down to the discredited Copyist style (der Nachahmer). ${ }^{38}$ And Mengs does seem to allow for historical openings and resurgencies that have a chance nature - 'accidental causes' and 'good fortune' (2:140). But he maintains as axiomatic an underlying art historical principle that sets up a final dilemma: since all human thought and action tend toward progression, once perfect art has been reached by a Master artist every attempt to 'superadd' to what has been achieved - whether out of the competitive desire to surpass, or a genuine attempt to improve - the 'too much excellence' introduces what is unessential, novel, superfluous, and therefore renders the ensuing art faulty $(2: 117,122,130-31,136-67,146$, 152; P, 49, 115-16).

The dilemma is this: If canonic art is attainable at large in history more than once, decline will be periodic. If the rise and fall of painting is a permanent recurrence (also palimpsestic?), artistic leadership that asks one to learn the Beauty of Nature by imitating the Master artist leads one into a bind (2:106-7). If there is a canon for painting, then there is an entelechial closure to its possible development and epigones are ontologically inescapable. If there is an openendedness to what painting can become, is there then a binding canon?

Mengs's art historiographic account remains troubled by this dilemma. He is unsure about whether Raphael, who was the 'most divine,' entails that Correggio was lesser, or whether Correggio's 'adding' charm to Raphael's work which never reached for the grace beyond Expressive art means Correggio was not still more superlative (1:54-55; 3:52-53, 149; P, 53). Mengs's fundamental commitment in theory to canonic art, however, and his attempt at a millenial artwork in Parnassus attest to his desire to make the palimpsestic dilemma fertile. Mengs meant to restore to patrons and the up-and-coming generation of artists the accumulated treasure of art knowledge 'hidden in forgetfulness' (2:19). He accepted this Sisyphean task without demur as a good neoclassical Idealist should, until at age fifty-one he died from overwork.

The dilemmas in Mengs' thought and work bore the fruit of an art historiographic method because he dared attribute relational categories to art which was regarded as normative during cultural change. 
That Mengs identified a certain tradition (the fictional 'Greek' one represented by Raphael and Correggio) (2:91-92, 101-3) to be the canon, and misjudged innovation by a norm of simplification were neoclassical errors which impeded his insights. That he did face the dilemma of giving leadership in theoretical aesthetics, artistic style, and art historiography at a time of considerable cultural stress at least makes us aware today that there are such problems.

\author{
CALVIN SEERVELD \\ Institute for Christian Studies, Toronto
}

\title{
Notes
}

1 Cf Nikolaus Pevsner, Academies of Art past and present (Cambridge: Cambridge University Press, 1940), pp. 150-51.

2 J.N. de Azara's generous comment 'que todo lo que hay technico en la Historia del Arte de Vinkelman es de su amigo Mengs' ('Noticias de la vida y obras de Don Antonio Rafael Mengs,' in Obras de D. Antonio Rafael Mengs, ed., Joseph Nicholas de Azara [Madrid: Imprenta Real de la Gazeta, 1790], p. xxxv) is based on Mengs' undisputable connoisseurship. Cf Mengs' letter to Fabroni (in Opere, ed. Carlo Fea [Roma: Stamperia Paglarini, 1787], pp. 357-68); Otto Harnack, 'Raffael Mengs' Schriften und ihr Einfluss auf Lessing und Goethe' (1892) in Essais und Studien zur Literaturgeschichte (Braunschweig: Verlag von Friedrich Vieweg und Sohn, 1899), pp. 200-201; and Herbert von Einem introduction to Mengs, Briefe an Raimondo Ghelli und Anton Maron (Göttingen: Vandenhoeck \& Ruprecht, 1973), pp. 20-21. Thomas Pelzel (in Winckelmann, Mengs and Casanova: a reappraisal of a famous eighteenth-century forgery,' Art Bulletin 54 [1972], 300-15) might find support for his judgment on the apocryphal nature of Mengs' role in the incident of fooling Winckelmann in the fact that the original Spanish memoir by de Azara lacks the account of the incident which is given in the 1783 Italian Bassano edition on pp. lxxxiv-lxxxix.

$3 \mathrm{Cf}$ Goethe's letter of March 1788 as he was reading the new 1878 Fea edition of Mengs's works: 'Es ist in allem Sinne ein trefflich Buch ... Auch seinen Fragmenten über die Schönheit, welche manchem so dunkel scheinen, habe ich glückliche Erleuchtungen zu danken' (in Italienische Reise 1786-1788 [München: Hirmer Verlag, 1960], pp. 507-08). Also, Goethe's letter of 17 September 1799 to Knebel: 'Ausserdem habe ich jetzt mit Meyern die Kunstgeschichte des gegenwärtigen Jahrhunderts vor. Erst bis auf Mengs und Winckelmann, dann die Epoche die sie machten, und welche Wendung nach ihnen die Sachen genommen habe' (Briefe, ed. Mandelkow [Hamburg: Christian Wegner Verlag, 1964] p. 397. Cf Herbert von Einem, 'Goethe und die bildende Kunst' (1949) in Goethe-Studien (München: Wilhelm Fink Verlag, 1972), pp. 122-30. 
4 For convenience sake the complete English translation of the Works of Anthony Raphael Mengs, ed. J.N. de Azara, translator unknown (London: R. Faulder, 1796), is cited in the text by volume: pages.

5 This lengthy letter treatise to Ponz 'sobre el merito de los Quadros mas singulares que se conservan en el Palacio Real de Madrid' (1776) will be cited in the text from the John Talbot Dillon English translation from the Spanish and published as Sketches on the Art of Painting (London: R. Baldwin, Pater Noster Row, 1787) as (P, pages).

6 Pelzel depreciates Mengs' 'gospel of eclecticism' (Anton Raphael Mengs and Neoclassicism; his art, his influence and his reputation [Princeton University Ph.D. diss. under R. Rosenblum, 1968], pp. 117-19) out of a bias that shows itself later: '... in the final analysis, Mengs can only be considered, in both theory and practice, as having been eclectic and conservative rather than imaginative and revolutionary' (ibid., pp. 348-49). The fact that one man's boon is another man's bane and depends much upon the reader's own subjective perspective is documented by the opposite judgments of Mengs' younger contemporaries Carl Ludwig Fernow (cf Neuen Teutschen Merkur of 1795, quoted in Dieter Honisch, Anton Raphael Mengs und die Bildform des Früh-Klassizismus [Recklinghausen: Verlag Aurel Bourges, 1965], p. 15) and Goethe (cf supra n. 3).

7 The original source of this listing of elements for painting is probably found in book II of Leon Battista Alberti, De pictura (1435), par. 30-31, 35, 46: 'Picturam igitur circumscriptio, compositio et luminum receptio perficiunt.'

8 Cf Ulrich Cristoffel, Der Schriftliche Nachlass des Anton Raphael Mengs. Ein Beitrag zur Erklärung des Kunstempfindens im spätern 18. Jahrhundert (Ph.D. diss. under H. Wölfflin (Basel: Benno Schwabe \& Co., 1918]), p. 139 n. 18.

9 An example: Lodovico Dolce, Dialogo della Pittura intitolato l'Aretino, cited in W. Tatarkiewicz, History of Aesthetics (Hague: Mouton, 1974) 3:214: Deve il pittore procacciar non solo di imitar ma di superar la natura.' Mengs: '...si vedrà, che l'Arte può molto ben superar la Natura' (Opere [Bassano 1783 edition], 1:19).

10 Note (a) 'Stimava più di tutti il Lomazzo. FEA' in Opere, ed Fea (1787), p. xxxv.

11 G. Paolo Lomazzo, Idea del tempio della pittura (1590), chapter 17: 'Mà dirò bene che à mio parere chi volesse formare due quadri di somma profetione come sarebbe d'vno Adamo, \& d'un Eua, che sono corpi nobilissimi al mondo; bisognarebbe che l'Adamo si dasse à Michel Angelo da disegnare, à Titiano da colorare, togliendo la proportione, \& conuenienza da Rafaello, \& l'Eua si disegnasse da Rafaello, \& si colorisse da Antonio da Coreggio: che questi due sarebbero i miglior quadri che fossero mai fatti al mondo' (photographic reproduction, Hildesheim: Georg Olms Verlagsbuchhandlung, 1965, p. 60). Cf Rensselaer W. Lee, Ut Pictura Poesis: The humanistic theory of Painting (New York: W.W. Norton \& Co., 1967), pp. 9-16.

12 1762, 1765, 1771, 1774, 1778. Cf Winfried Lüdecke, 'Mengs-Bibliographie,' Repertorium für Kunstwissenschaft 40 (1917), 255-60.

13 Cf Tatarkiewicz on Lomasso, History of Aesthetics 3:208; and Erwin Panofsky on Bellori in Idea, a concept in art theory (1924), trans. J.J.S. Peake (Columbia: University of South Carolina Press, 1968), p. 106.

14 Cf J.N. de Azara, 'Noticias' in Obras (1780), pp. xxvi-xxviii. 
$15^{\prime} \ldots$ those pieces which are forced or overcharged, destroy the taste of the art, but the simply beautiful works accustom the eye to a more delicate sense ... The best Taste which Nature can give, is that of the Medium, since it pleases mankind in general' $(1: 26)$. Winckelmann articulates the thought two years later in 1764 with choice images: 'Durch die Einheit und Einfalt wird alle Schönheit erhaben ... Diejenige Harmonie welche unsern Geist entzückt, besteht nicht in unendlich gebrochenen, gekettelten und geschleisten Tönen, sondern in einfachen lang anhaltenden Zügen ... Nach diesem Begriff soll die Schönheit sein, wie das vollkommenste Wasser aus dem Schoosse der Quelle geschöpft, welches, je weniger Geschmack es hat, desto gesunder geachtet wird, weil es von allen fremden Theilen geläutert ist' (Geschichte der Kunst des Altertums par. I, iv. 2.1 [Leipzig: Verlag der Dürr'schen Buchhandlung, 1882], pp. 110-11).

16 Cf Otto Harnack, p. 199; Wilhelm Waetzoldt, 'Mengs als Kunsthistoriker,' Zeitschrift für Bildende Kunst N.F. 30 (1919), 122.

17 Winckelmann had discussed and enjoined this option already in his own Gedanken über die Nachahmung der Griechischen Wercke in der Mahlerey und BildhauerKunst (1755): 'Scheinet die Vorstellung möglich, so ist sie es nur allein durch den Weg der Allegorie, durch Bilder, die allgemeine Begriffe bedeuten' (in Kleine Schriften, Vorreden, Entwürfe, ed. Walther Rehm [Berlin: Walter de Gruyter \& Co., 1968], pp. 55-56). Winckelmann developed the theme again in Versuch einer Allegorie, besonders für die Kunst (1766).

18 Mengs, Alessandro Albani und Winckelmann - Idee und Gestalt des Parnass in der Villa Albani,' Storia dell'arte 30/31 (May-December 1977), 87-156 +60 plates.

19 S. Röttgen, pp. 114-21.

20 Cf Carl Justi, 'Der Cardinal Alexander Albani,' Preussische Jahrbücher 28 (1871), $338-43$.

21 'Der Künstler hat ein Werck vonnöthen, welches aus der gantzen Mythologie, aus den besten Dichtern alter und neuerer Zeiten, aus der geheimen Weltweissheit vieler Völcker, aus den Denckmählern des Altertums auf Steinen, Müntzen und Geräthen diejenige sinnliche Figuren und Bilder enthält, wodurch allgemeine Begriffe dichterisch gebildet worden' (Winckelmann, 'Gedanken' [1755], in Kleine Schriften, p. 57). 'Der Pinsel, den der Künstler führet, soll im Verstand getunckt seyn, wie jemand von dem Schreibe-Griffel des Aristoteles gesaget hat: Er soll mehr zu dencken hinterlassen, als was er dem Auge gezeiget, und dieses wird der Künstler erhalten, wenn er seine Gedancken in Allegorien nicht zu verstecken, sondern einzukleiden gelernet hat' (ibid., p. 59). 'Eine jede Idee wird stärker, wenn sie von einer oder mehr Ideen begleitet ist, wie im Vergleichungen, und um so viel stärker, je entfernter das Verhältniss von diesen auf jene ist ... Je mehr unerwartetes man in einem Gemälde entdecket, desto rührender wird es; und beydes erhält es durch die Allegorie' ('Erläuterung der Gedanken von der Nachahmung' [1756], in Kleine Schriften, p. 120).

22 Cf S. Röttgen, pp. 140-43.

23 Ibid., p. 128.

$24 \mathrm{Cf}$ '... an insipid and artificial style, as may be appreciated from Mengs' own Parnassus (Villa Albani, Rome, 1761)' in The Oxford Companion to Art, ed. Harold Osborne (Oxford: Clarendon Press, 1970), p. 768. Hugh Honour's insightful and 
magisterial summary of 'Classicism and Neo-classicism' does, however, fail on this point too: 'Belonging to the early, negative anti-Rococo phase of Neo-classicism, it [Mengs' Parnassus] seeks to do nor more than recreate a dream of classical perfection by a synthesis of antique sculpture and Raphael's paintings' (Neo-classicism [Harmondsworth: Penguin books, 1968], p. 32).

25 Röttgen is correct too in distinguishing the 'borrowing' of a motif or two, which Gerstenberg detects (Johann Joachim Winckelmann und Anton Raphael Mengs [Halle: Max Niemeyer Verlag, 1929], p. 14), from the 'completely other, over-all cast of the determining style' of what Mengs produced in contrast to the discovered pieces Mengs came to see. Cf S. Röttgen, p. 140.

26 Röttgen grounds and motivates historically the rigorous exceptionality of the Parnassus fresco and attributes its uniqueness to Winckelmann's dictation on this particular commission; cf Storia dell'arte 30 (1977), 137-39. Dieter Honisch downplays its Sonderstellung most, perhaps, in his formcritical problematics that stresses the continuity of Mengs' shift from ornamental motifs to use of the painting field for ordering the composition (cf A.R. Mengs und die Bildform, pp. 34-37). Pelzel debunks Mengs' whole contribution to 'the reformatory classicism' as only an 'episodic,' 'incidental factor' in Mengs' artistic corpus (A.R. Mengs and Neoclassicism, pp. 127, 367).

27 'The British contribution to the Neo-classical style in painting,' Proceedings of the British Academy 40 (1954), 58-59.

28 Cf Honisch, pp. 22, 26, although Honisch calls Mengs' Dresden altarpiece on 'Christ's Ascension' (1755-66) and the San Eusebio fresco (1757-58) loosely 'noch in barocker Tradition,' p. 27.

29 Another painting of these years reinforces the judgment; cf Pelzel on 'Augustus and Cleopatra,' pp. 99-108.

30 Honisch notes how Mengs appropriated Correggio's themes and even formal properties in his 'Passion scenes' of 1765-68 (pp. 31-32). Pelzel sees the Correggian hegemony in later Mengs as evidence for denying Mengs any serious role in the spread of neoclassical art (pp. 145-52, 348-52). But Pelzel finds the Parnassus in fact already retrogressive toward a Rococo formal Empfindung (pp. 126, 140)! and reads the late Mengs loosely back into 'the Baroque tradition' (p. 165). Herbert von Einem shows how Mengs struggled to modify neoclassically, as best he could, the heroicizing project of decorating the Spanish King's palace, e.g., the heroes in 'Hercules' Apotheosis' (c. 1762-75) sit, stand, and walk around, separate from the clouds, and weightless Doric columns replace the heavens in the 'Apotheosis of Emperor Trajan' (c. 1774-76) (Mengs, Briefe an Raimondo \& Maron, pp. 17-18). Every art historian stumbles to find accurate terms: Gerstenberg uses baroque classicism' (p. 27), and S. Röttgen 'Neo-seicentismus' (p. 145).

31 Rosenblum opens the door to this insight by identifying 'the Neoclassic Horrific,' 'the Neoclassic Erotic,' and 'the Neoclassic Stoic' - all modes of Neoclassicism; but he skews this insight when he understands at least 'the Neoclassic Horrific' to have a Romantic view of antiquity (cf Transformations in late eighteenth century art [Princeton: Princeton University Press, 1967], pp. 11, 20, 28). 'Neoclassic' and 'Romantic' were contemporary trends or 'periods,' in my judgment, and both looked back in time; but their driving forces excluded each other, and were as at odds as Sir Joshua Reynolds and William Blake. Cf C. Seerveld, Towards a car- 
tographic methodology for art historiography,' Journal of Aesthetics and Art Criticism 39 (no. 2, 1980), 148-49.

32 Pelzel translated estilo viziosos as 'Vicious Style' (p. 144). This slanted translation exemplifies the tendentious way Pelzel twists so many facts about Mengs's thought, making Mengs seem mean-tempered or simple-minded. Mengs is not, as Pelzel claims, 'most contemptible of all' on 'the Easy Style' either. Mengs's serious effort to give good painterly advice and tips on taste is very undoctrinaire and generous. On the 'vitiated style' Mengs writes: '... I do not condemn the authors, since great defects are often annexed to great accomplishment ...' (P, 15).

33 J.N. de Azara, 'Noticias,' p. xxxix.

34 Herbert von Einem seems to interpret the types of style as a psychological index of artistic dispositions: 'zwar in psychologischer Hinsicht als Unterscheidung von Begabungstypen' (Mengs, Briefe an Raimondo \& Maron, p. 18). While Mengs gives cause for such a reading occasionally ('I advise therefore all painters not to study Correggio if they have not sensibility like him.' 1:67), Waetzoldt sees the issue more sharply when he refers to the delineated Urstile as 'Anschauungs- und Gestaltungsweise' (Deutsche Kunsthistoriker [Leipzig: E.A. Seemann, 1921], 1:91-92). There may be the ready-made anthropology of facultates and the still earlier 'humours' psychology of Hippocrates, which was so popular in the Renaissance, behind Mengs' typology; but Mengs' schema is intent upon artistic matters more than on a roster of personality-archetypes.

35 Reynolds's Discourses come later (from 1769 on) and are a comparable, if less systematic, attempt to give structure to learning' critique and the history of art.

36 Cf Alexander Potts, Winckelmann's Interpretation of the History of Ancient Art in its Eighteenth Century Context (Warburg Institute, University of London, Ph.D. diss. under E.H. Gombrich, 1978), 2:476-78.

37 In fact, Mengs uses the abiding Hauptgattungen des Stils or Sehweisen to detail the change in a given painter's style: Velasquez shifts from painting in the Natural style to a Graceful style, to the Expressive and finally to the Beautiful style (2:82-83; P , 62-63); Murillo turned from the Natural style to one of sweet Loveliness (2:84; $\mathrm{P}, 64-65)$; Raphael went through three styles, the last and best was developed out of Raphael's appreciation for Michelangelo's Sistine chapel painting (2:133); in Correggio too Mengs carefully discerned three changes of style $(3: 26,38)$.

38 Geschichte der Kunst des Altertums par. I, iv, 3. 1-4, pp. 152-73. Cf Carl Justi, Winckelmann und sine Zeitgenossen (Leipzig: Verlag von F.C.W. Vogel, 1923) 3:154-58. 